\title{
Effect of cadmium on prolactin cell activity and plasma electrolytes in the freshwater teleost Oreochromis mossambicus
}

\author{
H. Fu, R.A.C. Lock and S.E. Wendelaar Bonga \\ Department of Animal Physiology, Faculty of Science, University of Nijmegen, Nijmegen, \\ The Netherlands
}

(Received 13 July 1988; accepted 1 October 1988)

\begin{abstract}
Exposure of tilapia to a sublethal cadmium (Cd) concentration $(10 \mu \mathrm{g} \mathrm{Cd} / 1)$ led after 4 days to a rapid and substantial decrease of plasma total $\mathrm{Ca}$ and a small drop in plasma osmolarity and $\mathrm{Na}^{+}$. This ionic disturbance was only transitory and control levels were reached after 14 days. Prolactin is implicated in this recovery since prolactin cell activity increased markedly during the first 4 days. The gradually decreasing activity of prolactin cells thereafter points to induction of a second mechanism sustaining the resistance of fish to $\mathrm{Cd}$. In spite of the pronounced hypocalcemia, no apparent signs of demineralisation of bony tissues were observed. Since administration of prolactin to tilapia is known to exert a hypercalcemic action by increasing the net branchial $\mathrm{Ca}^{2+}$-uptake, it is concluded that restoration of $\mathrm{Cd}$ induced hypocalcemia is connected with the observed stimulation of prolactin cell activity.
\end{abstract}

Key words: Cadmium; Tilapia; Teleost fish; Ion balance; Calcium

\section{INTRODUCTION}

Exposure of freshwater fish to cadmium (Cd) in the water could lead to a disturbance of the calcium (Ca) balance (Roch and Maly, 1979; Giles, 1984; Yamawaki et al., 1986; Pratap et al., 1989). This hypocalcemic effect is apparently caused mainly by inhibition of $\mathrm{Ca}^{2+}$-uptake via the gills (Verbost et al., 1987; Reid and McDonald, 1988). Indeed, symptoms of $\mathrm{Cd}$ poisoning in fish such as hyperexcitability, rhythmic muscle contraction, and tetanic body movements (Pascoe and Mattey, 1977; Roch and Maly, 1979; Larsson et al., 1981) strongly resemble those of hypocalcemia (Doneen, 1976).

In contrast to lethal $\mathrm{Cd}$ concentrations whereby the blood Ca-level is permanently disturbed, and which is associated with a complete disruption of the ion- and water

Correspondence to: Dr. R.A.C. Lock, Department of Animal Physiology, Faculty of Science, University of Nijmegen, Toernooiveld, 6525 ED Nijmegen, The Netherlands. 
balance, a specific but transitory drop in plasma $\mathrm{Ca}$ can often be seen following exposure of fish to sublethal Cd concentrations (Giles, 1984; Yamawaki et al., 1986; Pratap et al., 1989). Most attention to explain this recovery of Cd-induced hypocalcemia has been focused on the role of metal-binding proteins sequestering intracellular Cd (Webb, 1979; Klaverkamp et al., 1984). However, since water and ion balance in fish are under endocrine control, hormones are also expected to play a role in counter-acting $\mathrm{Cd}$-induced ionic disturbances. In this respect the pituitary hormone prolactin should be mentioned, since it is with cortisol one of the main osmoregulatory hormones in freshwater fish (Loretz and Bern, 1982). Prolactin has hypercalcemic actions in teleost fish. Injections of prolactin or ectopic transplants of prolactin lobes induce hypercalcemia in different species of fish (Pang, 1981; Wendelaar Bonga et al., 1984; Flik et al., 1986). Conversely, hypophysectomized fish become hypocalcemic, exhibiting severe tetanic convulsions (Pang et al., 1973; Doneen, 1976). It seems reasonable therefore to predict that Cd-induced hypocalcemia is off-set, at least initially, by an increase of prolactin release. Involvement of prolactin is furthermore indicated since this hormone is known to promote activity and proliferation of mucus cells (Marshall, 1979; Wendelaar Bonga and Meis, 1981), and increased mucus secretion has been observed in Cd-exposed fish (Varanasi and Markey, 1978). After establishing the level of $\mathrm{Cd}$ which induces a transitory change in plasma osmolarity, we studied the effect of this sublethal $\mathrm{Cd}$ concentration on prolactin cell activity and on some physiological parameters controlled by this hormone: plasma $\mathrm{Na}^{+}$and total $\mathrm{Ca}$. In addition, potentially exchangeable calcium and phosphate stores of different bony tissues were measured. This study is part of an investigation into the role of hormones in the acclimation of fish to cadmium.

\section{MATERIALS AND METHODS}

Animals Freshwater male tilapia, Oreochromis mossambicus of 16 to $25 \mathrm{~g}$ body weight were obtained from our own laboratory stock. Fish were acclimated in 100-l aquaria on a 12-h photoperiod for at least three weeks before the start of the experiment. Aquaria contained circulating filtered Nijmegen tap water (main ion concentration in nmol/l: $\mathrm{Ca}, 0.8 ; \mathrm{Na}, 1.9 ; \mathrm{K}, 0.05 ; \mathrm{Cl}, 3.1 ; \mathrm{Mg}, 0.2 ; \mathrm{pH} 7.5$ ) of $28^{\circ} \mathrm{C}$. Animals were daily fed with Tetramin tropical fish food up till $24 \mathrm{~h}$ before sacrifice.

Experimental design To establish the effect of $\mathrm{Cd}$ on the plasma osmolarity, we exposed in a preliminary experiment tilapia to $\mathrm{Cd}$ of $1,10,100$ and $1000 \mu \mathrm{g} \mathrm{Cd} / \mathrm{l}$. The Cd concentration causing a transitory effect on the osmolarity (and total plasma $\mathrm{Ca}$ ) was selected for further experimentation. Experiments were started after addition of a predetermined aliquot from a stock $1 \mathrm{mg} \mathrm{Cd} / \mathrm{ml}$ solution of $\mathrm{Cd}\left(\mathrm{NO}_{3}\right)_{2}$ (RCB, Brussels) to the water. Concentrations were daily monitored by atomic absorption spectrophotometry (Video II, Thermo Jarrell Ash USA) at $228.8 \mathrm{~nm}$, and 
adjusted if necessary. Detection limit was $0.5 \mu \mathrm{g} \mathrm{Cd} / 1$. Fish were exposed to $\mathrm{Cd}$ for $2,4,14$ and 35 days. To assure that $\mathrm{Cd}$-exposed and control fish were of identical holding history, a control group was taken concurrently with each experimental group.

Sacrifice Fish were killed at indicated time intervals by spinal dissection, body weight recorded and blood plasma collected. Pituitaries were quickly excised for electron microscopical examination, and scales, operculum and vertebral bone removed for the analysis of calcium and phosphate content.

Blood plasma parameters Total plasma osmolarity was determined with a micro-osmometer (Vogel, Giessen, FRG). Plasma sodium was determined by flame photometer (Model IV Auto-Analyzer, Technicon). Plasma total calcium was determined spectrophotometrically by the cresolphthalein complexone method (Sigma).

Prolactin cell activity Pituitary glands of control and Cd-exposed fish were fixed for electron microscopy as described by Wendelaar Bonga and Van der Meij (1980), dehydrated and embedded in Spurr's resin. Ultrathin sections were examined under a Philips 301 electron microscope. For quantitative evaluation of prolactin cells, randomly selected samples of cell profiles at least totalling 20 cells per animal, were analyzed. Electron micrographs of these cells were scanned using a Kontron Digiplan integration equipment with magnetostriction tablet. The fractional volumes (relative to cytoplasmic volume) of granular endoplasmic reticulum (GER), Golgi apparatus $(\mathrm{Ga})$, and secretory granules (GRAN) were determined. For details see Wendelaar Bonga and Van der Meij (1980).

Tissue $\mathrm{Ca}$ and $\mathrm{PO}_{4}$ analyses Three types of bone samples viz. scales, operculum and vertebral bone were taken from each fish. Samples of 10 scales each were taken from both sides at the lateral line region directly posterior to the gill chamber. A sample of opercular bone $\left( \pm 0.5 \mathrm{~cm}^{2}\right)$ was taken, from which skin and connective tissue were removed by rubbing with tissue paper until it became transparent. A sample of vertebrae at the caudal end was removed and cleaned from adhering soft tissues. All bony samples were dried overnight at $90^{\circ} \mathrm{C}$ and dry weights determined to the nearest $0.01 \mathrm{mg}$. The dried samples were subsequently dissolved in $0.5 \mathrm{ml}$ concentrated $\mathrm{HNO}_{3}$ and the sample volume brought to $5 \mathrm{ml}$ with distilled water. Calcium and phosphate concentrations were measured by Inductively Coupled Plasma Atomic Emission Spectrometer (Plasma IL200, Thermo Electron, USA) and expressed as $\mathrm{mmol} / \mathrm{g}$ dry weight.

Statistics Differences between Cd-exposed and control groups were tested for significance by analysis of variance (ANOVA) and Student's $t$ test. Tests were twosided at the $5 \%$ significance level.

\section{RESULTS}

Plasma osmolarity Exposure of tilapia to $1000 \mu \mathrm{g} \mathrm{Cd} / 1$ resulted in a high acute mortality. After 2 days, a significant drop $(P<0.01)$ in plasma osmolarity was 


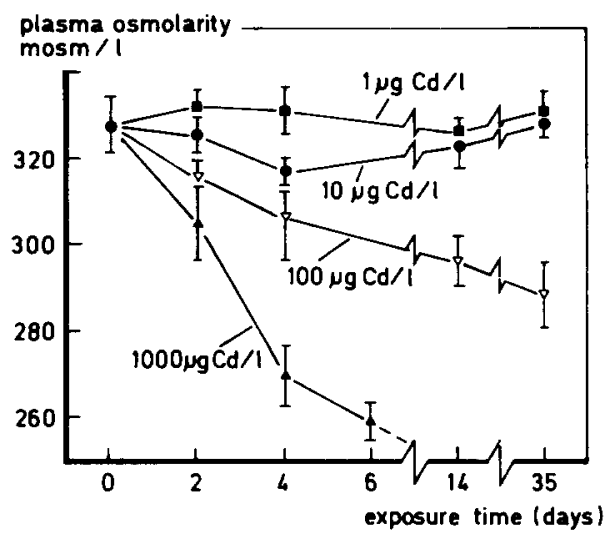

Fig. 1. Plasma osmolarity of tilapia after exposure for 2, 4, 14 and 35 days to indicated cadmium concentrations. Data are mean $\pm \mathrm{SE}$ of 8 observations; at $1000 \mu \mathrm{g} \mathrm{Cd} / 1$ all fish died within 8 days.

observed (Fig. 1). After 4 days when the first fish started to die, plasma osmotic values had further dropped in the remaining fish and symptoms of Cd-poisoning such as erratic body movements, tetanic seizures and hyper-excitability were noticeable. At this point the experiment was terminated as the remaining fish became moribund. Exposure of fish to $100 \mu \mathrm{g} \mathrm{Cd} / 1$ resulted initially in a low mortality; $<15 \%$ died during the first 2 wk. However, a significant drop $(P<0.01)$ in plasma osmolarity became already apparent after $48 \mathrm{~h}$ and continued until the end of the experiment (Fig. 1). Of the remaining fish more than $70 \%$ died in the following weeks, most of them in week 5 . Plasma total Ca levels were also severely affected, reaching levels as low as $45 \%$ of control values $(1.6 \pm 0.3 \mu \mathrm{mol} / \mathrm{l} \mathrm{Ca})$.

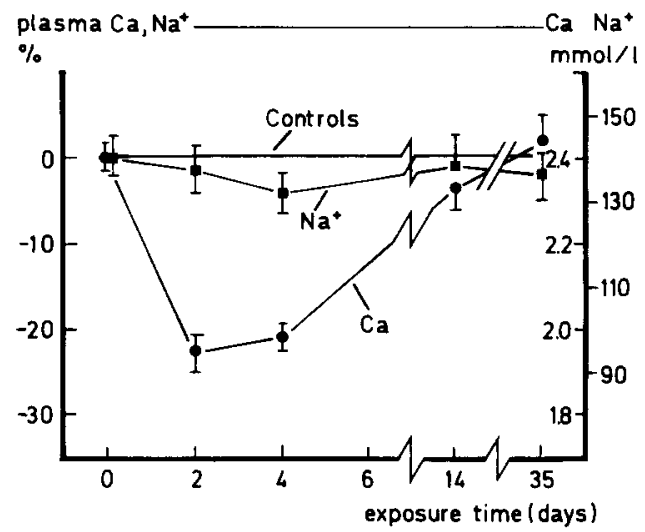

Fig. 2. Plasma total $\mathrm{Ca}$ and $\mathrm{Na}^{+}$after exposure to $10 \mu \mathrm{g} \mathrm{Cd} / 1$ at indicated time; mean $\pm \mathrm{SE}$ of 8 fish indicated. 

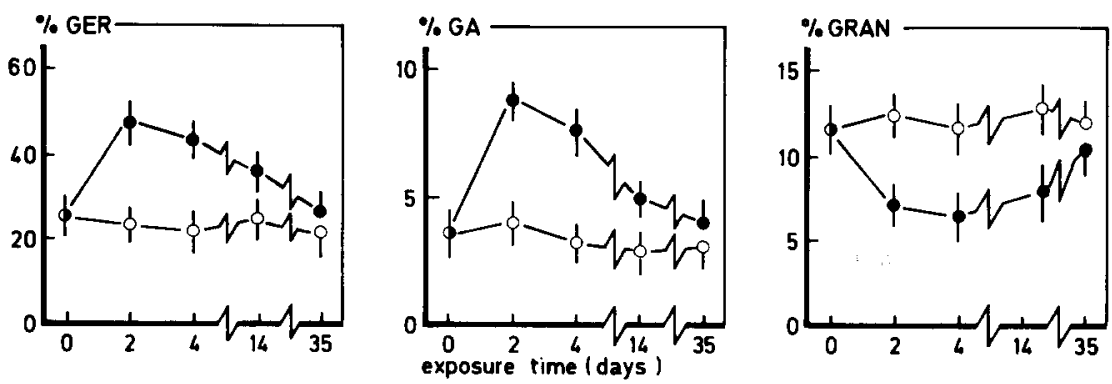

Fig. 3. Morphometrical data of prolactin cells of control tilapia ( $(0)$ and of fish exposed to $10 \mu \mathrm{g} \mathrm{Cd} / \mathrm{l}$ $(\bullet)$. Volumes of granular endoplasmic reticulum $(\mathrm{Ger})$, Golgi area $(\mathrm{Ga})$ and hormone-containing granules (Gran) are expressed as percentage of cytoplasmic volume. Mean \pm SE of 5 fish.

Moribund fish exhibited similar symptoms of Cd-poisoning as observed in tilapia exposed to $1000 \mu \mathrm{g} \mathrm{Cd} / 1$. At $10 \mu \mathrm{g} \mathrm{Cd} / 1$ mortality was not significantly different from controls, and no symptoms of $\mathrm{Cd}$ poisoning were observed during the experimental period. However, a small drop in plasma osmolarity was observed during the first few days, leading to a slight but significant $(P<0.05)$ change in plasma osmolarity at day 4 , which had disappeared at day 14 (Fig. 1). At $1 \mu \mathrm{g} \mathrm{Cd} / 1$, no mortality or changed plasma osmotic values were noticeable. A Cd concentration of 10 $\mu \mathrm{g} \mathrm{Cd} /$, which was considered sublethal but led to a transitory drop of the plasma osmolarity, was selected for further experiments.

Plasma $\mathrm{Na}^{+}$and plasma total $\mathrm{Ca}$ Exposure of tilapia to $10 \mu \mathrm{g} \mathrm{Cd} / \mathrm{l}$ led to a small but significant drop ( $P<0.05$ after 4 days) in plasma $\mathrm{Na}^{+}$, which had completely disappeared in the following weeks (Fig. 2). Plasma total Ca levels showed a pronounced decrease of $23 \%$ and $21 \%(P<0.01)$ after respectively 2 and 4 days of exposure. This initial drop was followed by a rapid recovery, resulting in Calevels not significantly different from control levels in the following weeks (Fig. 2).

Prolactin cell morphometry Morphometrical and ultrastructural examination of prolactin cells of fish exposed for different times to $10 \mu \mathrm{g} \mathrm{Cd} / \mathrm{I}$ showed marked changes, indicative for enhanced prolactin release (Figs. 3-5). During the first week of exposure, the extent of granular endoplasmic reticulum (GER) and Golgi area (Ga) had significantly $(P<0.01)$ increased, while a marked $(P<0.01)$ drop in hormone-containing granules was observed (Fig. 3). This difference is further illustrated in the electron micrograph of prolactin cells from control fish (Fig. 4) and fish exposed to $\mathrm{Cd}$ for 4 days (Fig. 5). Increased prolactin cell activity appeared transitory; no significant differences between control and Cd-exposed fish were observed after 35 days.

Figs. 4 and 5. Prolactin cells of control tilapia (Fig. 4) and of fish exposed for 4 days to $10 \mu \mathrm{g} \mathrm{Cd} / \mathrm{l}$ (Fig. 5). Cd-exposed fish show more granular endoplasmic reticulum (Ger), more extensive Golgi area (Ga) and less hormone containing granules (Gran); $11000 \times$. 


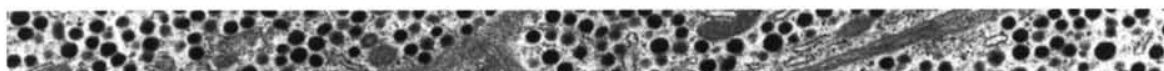

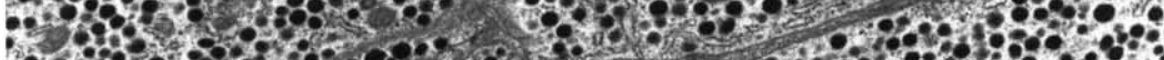

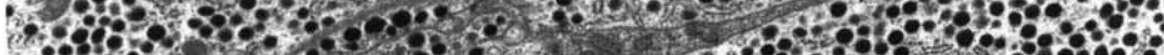

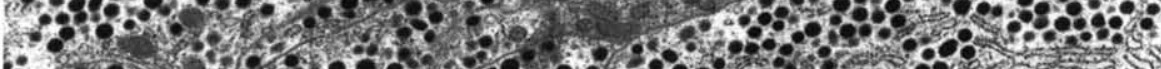

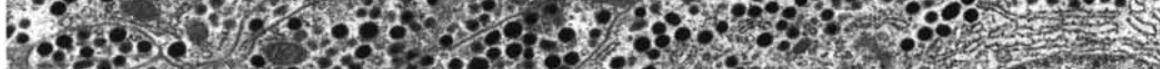
38.

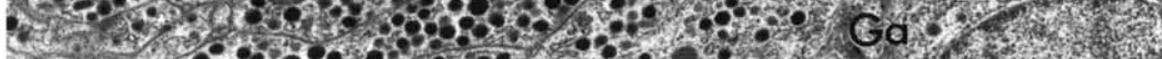

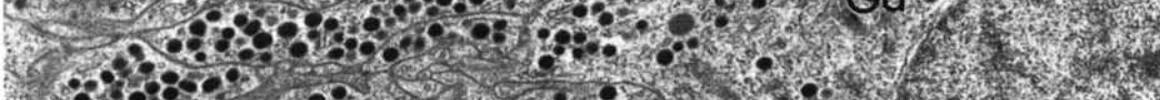

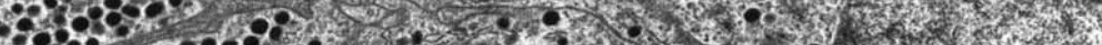

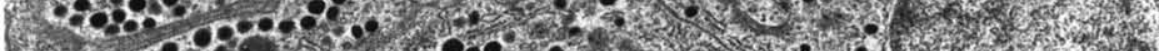

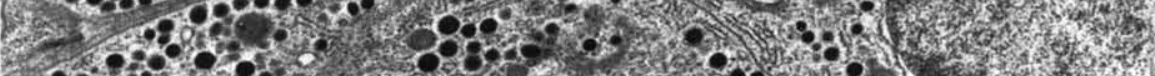

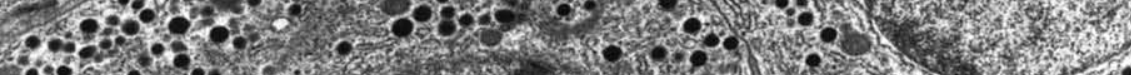

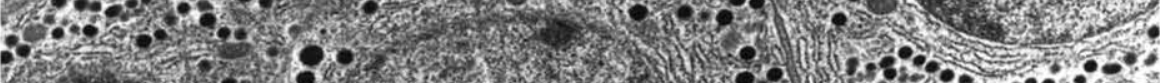

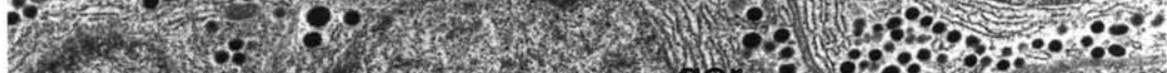

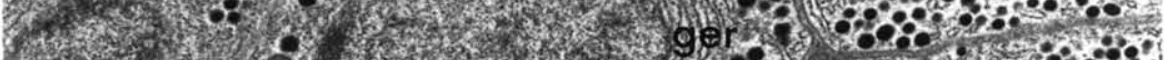

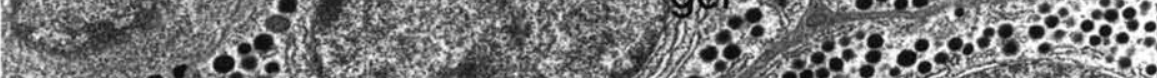

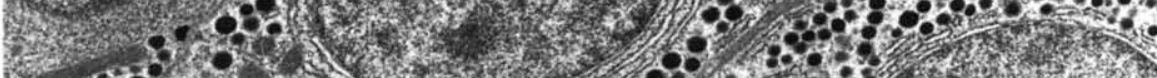
-

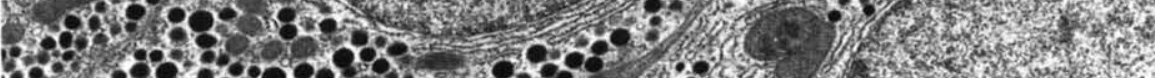

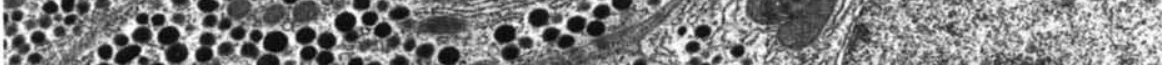

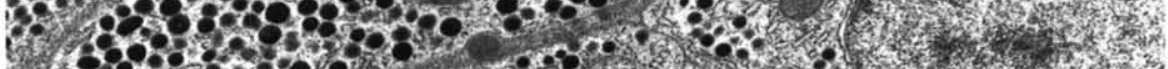

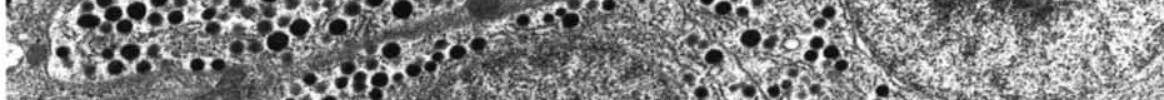

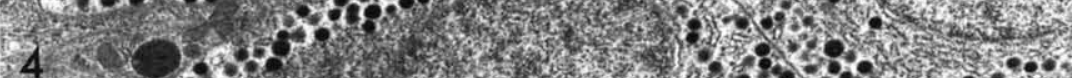

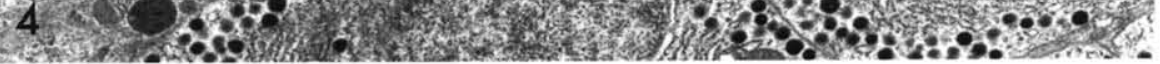

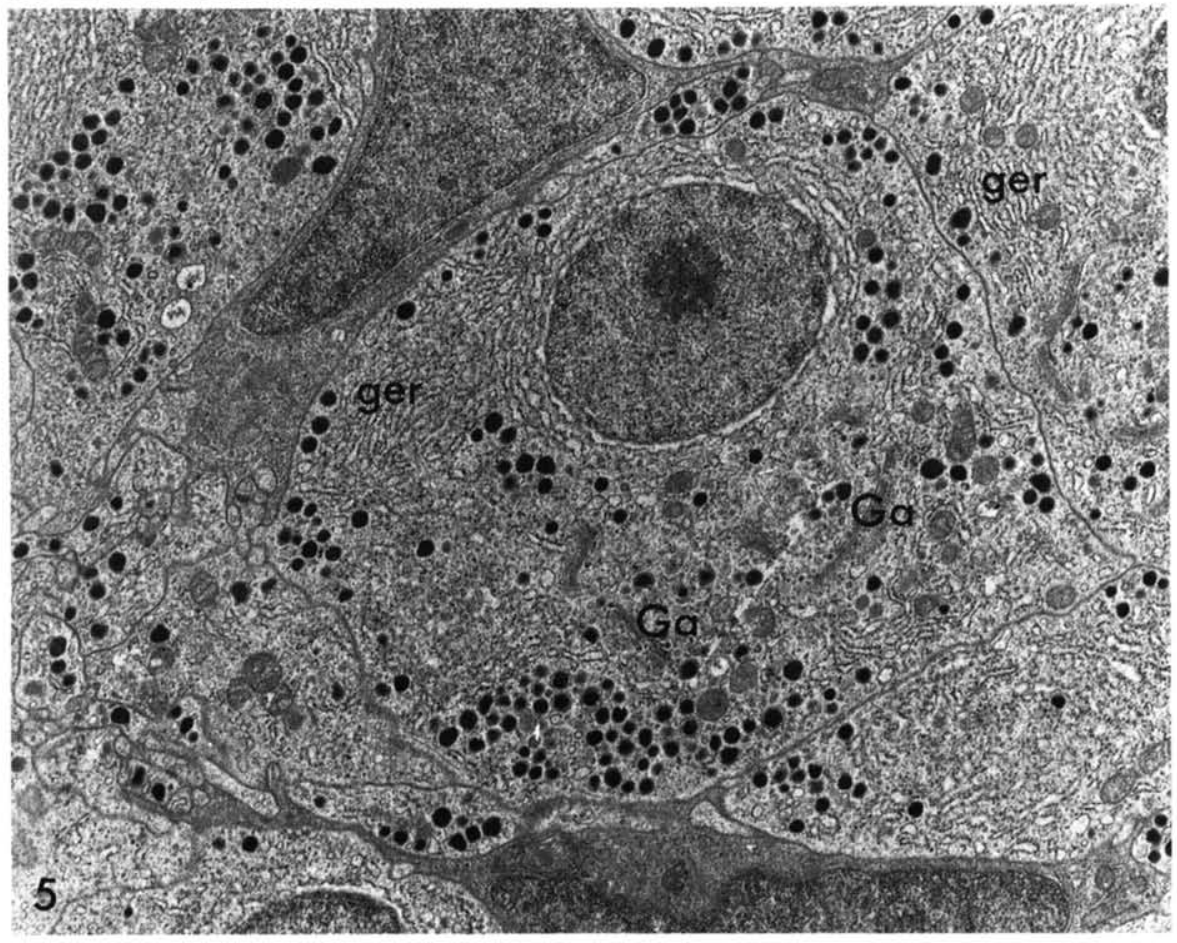




\section{TABLE I}

Calcium (Ca) and phosphate $\left(\mathrm{PO}_{4}\right)$ content (mmol/g dry weight) and $\mathrm{Ca} / \mathrm{PO}_{4}$ ratio in scales, operculum and vertebrae of control tilapia (Oreochromis mossambicus) and of fish exposed to $10 \mu \mathrm{g} \mathrm{Cd} / 1$ for 2 and 14 days.

\begin{tabular}{llllllll}
\hline & \multicolumn{2}{l}{ Control fish } & & & \multicolumn{3}{l}{ Cd-exposed fish } \\
\cline { 2 - 3 } \cline { 6 - 7 } & $\mathrm{Ca}$ & $\mathrm{PO}_{4}$ & $\mathrm{Ca} / \mathrm{PO}_{4}$ & $\mathrm{Ca}$ & $\mathrm{PO}_{4}$ & $\mathrm{Ca} / \mathrm{PO}_{4}$ \\
\hline 2 Days & & & & & & \\
Scales & $3.91 \pm 0.40$ & $2.64 \pm 0.25$ & $1.48 \pm 0.01$ & $3.83 \pm 0.31$ & $2.59 \pm 0.20$ & $1.48 \pm 0.02$ \\
Operculum & $4.93 \pm 0.22$ & $3.26 \pm 0.14$ & $1.51 \pm 0.01$ & $5.01 \pm 0.18$ & $3.31 \pm 0.12$ & $1.52 \pm 0.01$ \\
Vertebrae & $3.72 \pm 0.14$ & $2.55 \pm 0.11$ & $1.46 \pm 0.02$ & $3.41 \pm 0.12$ & $2.31 \pm 0.19$ & $1.47 \pm 0.02$ \\
& & & & & & \\
14 Days & & & & & & \\
Scales & $3.74 \pm 0.23$ & $2.51 \pm 0.14$ & $1.49 \pm 0.03$ & $3.55 \pm 0.95$ & $2.43 \pm 0.41$ & $1.43 \pm 0.13$ \\
Operculum & $4.29 \pm 0.34$ & $2.65 \pm 0.16$ & $1.51 \pm 0.03$ & $4.19 \pm 0.16$ & $2.81 \pm 0.11$ & $1.49 \pm 0.02$ \\
Vertebrae & $3.58 \pm 0.45$ & $2.37 \pm 0.39$ & $1.51 \pm 0.06$ & $3.84 \pm 0.31$ & $2.62 \pm 0.18$ & $1.47 \pm 0.05$ \\
\hline
\end{tabular}

Values are expressed as mean \pm SE of 10 observations.

Tissue Ca and $\mathrm{PO}_{4}$ analysis The content of $\mathrm{Ca}$ and $\mathrm{PO}_{4}$ as well as the $\mathrm{Ca} / \mathrm{PO}_{4}$ ratio of scales, operculum and vertebral bone in controls and $\mathrm{Cd}$-exposed fish are shown in Table I. No alteration in $\mathrm{Ca}$ and $\mathrm{PO}_{4}$ content or their ratio is observed in any of the tissues examined during the experimental period of $5 \mathrm{wk}$ (only data of fish after 2 and 14 days of exposure are shown).

\section{DISCUSSION}

Exposure to $1000 \mu \mathrm{g} \mathrm{Cd} / 1$ proved to be lethal to tilapia. Observations by others on the same and different species of fish have shown $\mathrm{Cd}$-concentrations at this level to be critical (Morgan, 1976; McCarty et al., 1978; Majewski and Giles, 1981; Pascoe et al., 1986). Although no acute toxicity was observed at $100 \mu \mathrm{g} \mathrm{Cd} / \mathrm{l}$ during the first week of exposure, the gradual reduction of plasma osmolarity leading to a high mortality in the following weeks reflects the inability of the fish to regain proper water and ion homeostasis. This disturbance in osmoregulation at $\mathrm{Cd}$ concentrations of this level is a probable consequence of gill and kidney damage as frequently reported for Cd-intoxicated fish species (Gardner and Yevich, 1970; Stromberg et al., 1983; Karlsson-Norrgren et al., 1985). The Cd-induced injuries are apparently of such serious nature that normal mechanisms of regulation are incapable of restoring the ion balance.

Except for a small but significant drop in plasma osmolarity after 4 days of exposure to $10 \mu \mathrm{g} \mathrm{Cd} / \mathrm{l}$, no further changes in plasma total osmolarity were observed, indicating an intact osmoregulation. In contrast, a serious and specific drop in plasma total Ca-level was observed after 2 days of exposure. This rapid induction of hypocalcemia by sublethal concentrations of $\mathrm{Cd}$ has also been shown in rainbow 
trout (Roch and Maly, 1979; Giles, 1984), flounder (Larsson et al., 1981), carp (Koyama and Itazawa, 1977; Yamawaki et al., 1986), and tilapia (Pratap et al., 1989). It reflects a specific reduction of $\mathrm{Ca}^{2+}$-uptake via the gills as demonstrated in rainbow trout (Verbost et al., 1987; Reid and McDonald, 1988). At lethal Cdconcentrations branchial $\mathrm{Ca}^{2+}$-uptake in these fish has even been shown to be completely inhibited (Verbost et al., 1987). Severe hypocalcemia became also apparent in our tilapia exposed to $100 \mu \mathrm{g} \mathrm{Cd} / 1$ and above where plasma Ca-levels in moribund fish had dropped with almost $45 \%(1.6 \pm 0.3 \mathrm{mmol} \mathrm{Ca} / \mathrm{l})$.

Since $\mathrm{Ca}$ is of crucial importance in maintaining integrity and stability of gill epithelial cell membranes (Wendelaar Bonga et al., 1983), as well as to the development of action potentials in muscle and nerve cells (Prosser, 1973), a pronounced alteration of plasma $\mathrm{Ca}$ concentration will severely affect these processes. In mammals for example, decreased plasma Ca-concentrations are known to cause neuromuscular hyperexcitability and cramp conditions, so-called hypocalcemic tetanus (Ganong, 1975). It is quite likely therefore that severe hypocalcemia is the major cause for the tetanic body movements and loss of blood ions as observed in $\mathrm{Cd}$-intoxicated tilapia. Similar neuromuscular effects of $\mathrm{Cd}$ have been observed in minnows (Bengtsson et al., 1975), flounder (Larsson et al., 1981), and rainbow trout (Roch and Maly, 1979; Giles, 1984). Indeed, Roch and Maly (1979) considered extreme hypocalcemia as the primary cause of death of $\mathrm{Cd}$-intoxicated freshwater fish.

In contrast to fish exposed to $100 \mu \mathrm{g} \mathrm{Cd} / 1$ and above, only a transitory disruption of the Ca-balance was observed in tilapia exposed to $10 \mu \mathrm{g} \mathrm{Cd} / 1$. This phenomenon has also been reported for rainbow trout (Giles, 1984), carp (Yamawaki et al., 1986) and tilapia (Pratap et al., 1988), indicating a successful process of detoxification or acclimation. The question as to which biochemical and physiological mechanisms are primarily responsible for this restoration of plasma Ca-levels is rather unclear. Although detoxification by $\mathrm{Cd}$-binding proteins such as metallothioneins (MT) undoubtedly plays a crucial role in sustaining long term acclimation to $\mathrm{Cd}$ (Webb, 1979; Klaverkamp et al., 1984), we propose that prolactin is initially involved in counteracting $\mathrm{Cd}$-induced hypocalcemia in fish. Our arguments are the following: prolactin is with cortisol one of the main osmoregulatory hormones in fish. Prolactin has been implicated in the maintenance of plasma electrolyte levels, mainly by controlling permeability of the gill epithelium (Clark and Bern, 1980). This action of prolactin has also been demonstrated for tilapia (Dharmamba and Maetz, 1972; Wendelaar Bonga et al., 1983). Moreover, in tilapia and other freshwater fish, prolactin has a specific action on Ca-metabolism. It has been shown to promote hypercalcemia in various species of fish, mainly via increased net uptake rate of $\mathrm{Ca}^{2+}$ via the gills (Pang et al., 1973; Wendelaar Bonga and Flik, 1982; Flik et al., 1986). A response of prolactin to $\mathrm{Cd}$-induced hypocalcemia is therefore expected. Our results show that hypocalcemia is indeed related with increased activity of prolactin cells. One of the most striking features observed was a degranulation of prolactin cells, which together with the increased volumes of granular endoplasmic reticulum 
(GER) and Golgi area (GA) is considered as a reliable indicator of prolactin release (Wendelaar Bonga et al., 1984). Moreover, these changes were most pronounced at the time (day 4) of severest hypocalcemia supporting the role of prolactin as hypercalcemic hormone. Other than stimulating the active $\mathrm{Ca}^{2+}$-uptake via the gills, prolactin may also exert its hypercalcemic action via remobilization of $\mathrm{Ca}$ from exchangeable Ca-stores. Bone demineralization has been shown in Cd-exposed carp (Koyama and Itazawa, 1977; Muramoto, 1981) and has been interpreted as a mechanism to restore plasma Ca-levels. We have no evidence in support of a similar mechanism taking place in tilapia since no decrease in $\mathrm{Ca}$ and $\mathrm{PO}_{4}$ content of exchangeable Ca-stores was observed. Even in tilapia exposed to a lethal $\mathrm{Cd}$ concentration of $1000 \mu \mathrm{g} \mathrm{Cd} / \mathrm{l}$, which resulted in severe hypocalcemia, no changes in $\mathrm{Ca}$ and $\mathrm{PO}_{4}$ content of bony tissues were apparent (results not shown). The reason for this discrepancy between carp and tilapia is a likely result of the different bone structure between these fish. In contrast to carp, which possesses cellular bone, tilapia has acellular bone, which by its absence of enclosed osteocytes is dead tissue and therefore unavailable for cellular calcium mobilization (Moss, 1965). Since freshwater fish take up most of their calcium required for growth and Ca-homeostasis directly via their gills (Flik et al., 1985), a process stimulated by prolactin (Flik et al., 1986), an increased branchial net Ca-flux via increased prolactin secretion appears the most obvious explanation for the observed restoration of plasma $\mathrm{Ca}$ levels.

To our knowledge the effect of Cd on prolactin cell activity is restricted to one other study by James and Wigham (1986). They could not find any consistent effect on prolactin cell activity in rainbow trout after $\mathrm{Cd}$ treatment via intraperitoneal injection, water exposure or in vitro incubation of pituitaries with cadmium. This discrepancy with our results is probably due to the extremely high Cd-concentration used in their study (up to 500 times the $96-\mathrm{h} \mathrm{LC}_{50}$ value), which could block any adaptive response. An analogous observation was reported in acid-stressed tilapia in our laboratory, where strong activation of prolactin cells was blocked after lethal $\mathrm{pH}$ levels were reached (Wendelaar Bonga et al., 1987).

One of the remarkable observations in this study was that the increased prolactin cell activity did not continue during the entire $\mathrm{Cd}$-exposure period. If $\mathrm{Cd}$ continues to exert its hypocalcemic action one would expect a permanently elevated level of prolactin release to counter-act this effect. That this did not happen points to the induction of a second mechanism like increased capacity to sequester intracellular $\mathrm{Cd}$ by metal-binding proteins in the gills. Whether induction of these proteins is directly stimulated by prolactin or indirectly through actions of cortisol is currently investigated.

\section{ACKNOWLEDGEMENTS}

We thank Mr Coen van der Meij and Mr Tom Spanings for their technical 
assistance, and Mrs Elizabeth Jansen-Hoorweg for her secretarial help. This study was financially supported by the Dutch Ministry of Education and Sciences and by the Nijmegen Foundation for the Advancement of Co-operation with Foreign Universities.

\section{REFERENCES}

Bengtsson, B.-E., C.H. Carlin, A. Larsson and O. Svanberg, 1975. Vertebral damage in minnows Phoxinus phoxinus L. exposed to cadmium. Ambio 4, 166-168.

Clark, W.C. and H.A. Bern, 1980. Comparative endocrinology of prolactin. In: Hormonal proteins and peptides, vol. VIII, edited by C.H. Li, Academic Press, New York, pp. 105-197.

Dharmamba, M. and J. Maetz, 1972. Effects of hypophysectomy and prolactin on the sodium balance of Tilapia mossambica in fresh water. Gen. Comp. Endocrinol. 19, 175-183.

Doneen, B.A., 1976. Biological activities of mammalian and teleostean prolactins and growth hormones on mouse mammary gland and teleost urinary bladder. Gen. Comp. Endocrinol. 30, 34-42.

Flik, G., J.C. Fenwick, Z. Kolar, N. Mayer-Gostan and S.E. Wendelaar Bonga, 1985. Whole-body calcium flux rates in cichlid teleost fish Oreochromis mossambicus adapted to fresh water. Am. J. Physiol. 249, R432-R437.

Flik, G., J.C. Fenwick, L. Kolar, N. Mayer-Gostan and S.E. Wendelaar Bonga, 1986. Effects of ovine prolactin on calcium uptake and distribution in Oreochromis mossambicus. Am. J. Physiol. 250, R161-R166.

Foskett, J.K. and C. Scheffey, 1982. The chloride cell: definite identification as the salt-secretory cell in teleosts. Science $215,164-166$.

Foskett, J.K., G.D. Logsdon, T. Turner, T.E. Machen and H.A. Bern, 1981. Differentiation of the chloride extrusion mechanism during seawater adaptation of a teleost fish, the cichlid Sarotherodon mossambicus. J. Exp. Biol. 93, 209-224.

Ganong, W.F., 1975. Review of medical physiology, 17th ed. Lange Medical Publications, Los Altos, Cal., 529 pp.

Gardner, G.R. and P.P. Yevich, 1970. Histological and hematological responses of an estuarine teleost to cadmium. J. Fish. Res. Bd. Can. 27, 2185-2196.

Giles, M.A., 1984. Electrolyte and water balance in plasma and urine of rainbow trout (Salmo gairdneri) during chronic exposure to cadmium. Can. J. Fish. Aquat. Sci. 41, 1678-1685.

James, V.A. and T. Wigham, 1986. The effects of cadmium on prolactin cell activity and plasma cortisol levels in the rainbow trout (Salmo gairdneri). Aquat. Toxicol. 8, 273-280.

Karlsson-Norrgren, L., P. Runn, C. Haux and L. Förlin, 1985. Cadmium-induced changes in gill morphology of zebrafish, Brachydanio rerio (Hamilton-Buchanan), and rainbow trout Salmo gairdneri Richardson. J. Fish Biol. 27, 81-95.

Klaverkamp, J.F., W.A. MacDonald, D.A. Duncan and R. Wagemann, 1984. Metallothionein and acclimation to heavy metals in fish. A review. In: Monitoring contaminants in fish, edited by J.O. Nriaga, J. Wiley \& Sons, Inc., New York, pp. 99-113.

Koyama, J. and Y. Itazawa, 1977. Effects of oral administration of cadmium on fish. I. Analytical results of the blood and bones. Bull. Jpn. Soc. Sci. Fish. 43, 523-526.

Larsson, A., B.-E. Bengtsson and C. Haux, 1981. Disturbed ion balance in flounder, Platichthys flesus L. exposed to sublethal levels of cadmium. Aquat. Toxicol. 1, 19-36.

Loretz, C.A. and H.A. Bern, 1982. Prolactin and osmoregulation in vertebrates. Neuroendocrinology 35, 292-304.

Majewski, H.S. and M.A. Giles, 1981. Cardiovascular-respiratory responses of rainbow trout (Salmo gairdneri) during chronic exposure to sublethal concentrations of cadmium. Water Res. 15 , $1211-1217$. 
Marshall, W.S., 1979. Effects of salinity acclimation, prolactin, growth hormone, and cortisol on the mucous cells of Leptocottus armatus (Teleostei; Cottidae). Gen. Comp. Endocrinol. 37, 358-368.

McCarty, L.S., J.A.C. Henry and A.H. Houston, 1978. Toxicity of cadmium to goldfish, Carassius auratus in hard and soft water. J. Fish. Res. Bd. Can. 35, 35-42.

Morgan, W.S.G., 1976. Fishing for toxicity: biological automonitor for continuous water quality control. Effluent Water Treatment, pp. 471-475.

Moss, M.L., 1965. Studies of the acellular bone of teleost fish. V. Histology and mineral homeostasis of freshwater species. Acta Anat. 60, 262-276.

Muramoto, S., 1981. Vertebral column damage and decrease of calcium concentrations in fish exposed experimentally to cadmium. Environ. Pollut. (Ser. A) 24, 125-133.

Pang, P.K.T., 1981. Hypercalcemic effects of ovine prolactin on intact killifish, Fundulus heteroclitus, subjected to different environmental challenges. Gen. Comp. Endocrinol. 44, 252-255.

Pang, P.K.T., M.P. Schreibman and R.W. Griffith, 1973. Pituitary regulation of serum calcium levels in the killifish Fundulus heteroclitus. Gen. Comp. Endocrinol. 21, 536-542.

Pascoe, D. and S. Mattey, 1977. Studies in the toxicity of cadmium to the three-spined stickleback Gasterosteus aculeatus L. J. Fish Biol. 11, 207-215.

Pascoe, D., S.A. Evans and J. Woodworth, 1986. Heavy metal toxicity to fish and the influence of water hardness. Arch. Environ. Contam. Toxicol. 15, 481-487.

Payan, P., N. Mayer-Gostan and P.K. Pang, 1981. Site of calcium uptake in the freshwater trout gill. J. Exp. Zool. 216, 345-347.

Pratap, H.B., H. Fu, R.A.C. Lock and S.E. Wendelaar Bonga, 1989. Effect of water-borne and dietary cadmium on plasma ions of the teleost Oreochromis mossambicus in relation to water calcium levels. Arch. Environ. Contam. Toxicol., in press.

Prosser, C.L., 1973. Comparative animal physiology, 3rd ed., W.B. Saunders, Philadelphia, London, Toronto, pp. 96-106.

Reid, S.D. and D.G. McDonald, 1988. Effects of cadmium, copper, and low pH on ion fluxes in the rainbow trout, Salmo gairdneri. Can. J. Fish. Aquat. Sci. 45, 244-253.

Roch, M. and E.J. Maly, 1979. Relationship of cadmium-induced hypocalcemia with mortality in rainbow trout (Salmo gairdneri) and the influence of temperature on toxicity. J. Fish. Res. Bd. Can. 36, 1297-1303.

Stromberg, P.C., J.G. Ferrante and S. Carter, 1983. Pathology of lethal and sublethal exposure of fathead minnows, Pimephales promelas, to cadmium: a model for aquatic toxicity assessment. J. Toxicol. Environ. Hlth 11, 247-259.

Varanasi, U. and D. Markey, 1978. Uptake and release of lead and cadmium in skin and mucus of coho salmon. Comp. Biochem. Physiol. 60C, 187-192.

Verbost, P.M., G. Flik, R.A.C. Lock and S.E. Wendelaar Bonga, 1987. Cadmium inhibition of $\mathrm{Ca}^{2+}$ uptake in rainbow trout gills. Am. J. Physiol. 253, R216-R221.

Webb, M., 1979. The metallothioneins. In: The chemistry, biochemistry and biology of cadmium, edited by M. Webb, Elsevier/North-Holland, Biomedical Press, Amsterdam, pp. 195-266.

Wendelaar Bonga, S.E. and G. Flik, 1982. Prolactin and calcium metabolism in a teleost fish. In: Comparative endocrinology of calcium regulation, edited by C. Oguro and P.K. Pang. Tokyo: Scientific Societies Press, pp. 21-26.

Wendelaar Bonga, S.E. and S. Meis, 1981. Effects of external osmolality, calcium and prolactin on growth and differentiation of the epidermal cells of the cichlid teleost Sarotherodon mossambicus. Cell Tissue Res. 221, 109-123.

Wendelaar Bonga, S.E. and J.C.A. van der Meij, 1980. The effects of ambient calcium on prolactin cell activity and plasma electrolytes in Sarotherodon mossambicus. Gen. Comp. Endocrinol. 40, 391-401.

Wendelaar Bonga, S.E., C.J. Löwik and J.C.A. van der Meij, 1983. Effects of external $\mathrm{Mg}^{2+}$ and $\mathrm{Ca}^{2+}$ on branchial osmotic water permeability and prolactin secretion in the teleost fish Sarotherodon mossambicus. Gen. Comp. Endocrinol. 52, 222-231. 
Wendelaar Bonga, S.E., G. Flik and J.C. Fenwick, 1984. Prolactin and calcium metabolism in fish: effects on plasma calcium and high-affinity $\mathrm{Ca}^{2+}$-ATPase in gills. In: Endocrine control of bone and calcium metabolism, edited by D.V. Cohn, J.T. Potts, Jr. and J. Fujita, Elsevier, New York, pp. 188-190.

Wendelaar Bonga, S.E., G. Flik and P.H.M. Balm, 1987. Physiological adaptation to acid stress in fish. Ann. Soc. Roy. Zool. Belg. 117, 243-254.

Yamawaki, K., W. Hashimoto, K. Fujii, J. Koyama, Y. Ikeda and H. Ozaki, 1986. Hemochemical changes in carp exposed to low cadmium concentrations. Bull. Jpn. Soc. Sci. Fish. 52, 459-466. 